\title{
Gender Contract in Online Commercials in Japan: A Critical Investigation of the Contemporary Discourse on the Work-Life Balance
}

\author{
Ksenia Golovina \\ $\mathrm{PhD}$, Project Assistant Professor, Center for Global Communication Strategies, \\ College of Arts and Sciences, University of Tokyo \\ Address: Komaba 3-8-1, Meguro Ward, Tokyo, Japan, 153-8902 \\ E-mail: kgolovina@cgcs.c.u-tokyo.ac.jp
}

\begin{abstract}
This paper adopts a multimodal critical discourse analysis (MCDA) approach and examines how recent online commercials produced in Japan articulate the discourses pertaining to the trending concept of work-life balance (WLB). Further, the study analyzes the narratives of working mothers in Japan who were asked to watch the selected videos and share their thoughts on WLB. As such, it investigates the effects of the discourses transmitted through commercials on women's perceptions of their identities as workers, partners and mothers. The analysis of the multimodal data made it possible to identify the underlying discourses on WLB and gender roles conveyed through the videos. These hidden discourses were highly complex and generally contradicted the readily manifest messages of the respective commercials. One of the central messages in these discourses was the promotion of an apologetic attitude and empathy through one-time "heroic deeds" done by men for their wives. The study participants' narratives revealed their personal aspirations for a desirable WLB, while simultaneously unveiling how they unconsciously internalized many of the videos' discursive impositions. The study contributes to the application of critical discourse analysis methods and to the discussion on the reconstitution of gender roles, necessary for the implementation of both public and private WLB strategies, in Japan and elsewhere.
\end{abstract}

Keywords: work-life balance, multimodal critical discourse analysis, online commercials, gender roles, working mothers

\section{Introduction}

Recently, the concept of work-life balance (WLB) has been gaining currency in both public and private discourse in Japan. Since the adoption of the WLB Charter in 2007, the debate, in terms of policy, has centered on long working hours, a topic that it has explored in the larger context of female labor struggles, gender equality problems, and declining birthrates (Ikezoe, 2014). At the same time, WLB has become a somewhat fanciful construct suggesting a new, progressive worldview held by an individual who is conscious of their (and by extension, their family's) overall well-being. Japan's ruling party's "political promises" have introduced an additional level of complexity to this discussion, as the party has pledged to "create a society where women shine by exercising their individuality and talents, each in accordance with her own desires, in the family,

(c) Golovina K., 2018
(c) Centre for Fundamental Sociology, 2018
DOI: $10.17323 / 1728-192 \mathrm{X}-2018-1-160-191$ 
region, and workplace" (Liberal Democratic Party [LDP], 2014: 16). Notwithstanding this manifesto's arguably ideological underpinnings (which primarily concern Japan's prestige in the international arena [Schieder, 2014]), the term "shining women" has become a popular expression within everyday discourse in Japan, with the vision of attaining that goal currently preoccupying organizations and people in various positions. Realizing this vision largely depends on the reconstruction of traditional gender roles, and WLB in particular has the potential to play a crucial part in facilitating this process. While Japan's Gender Equality Bureau Cabinet Office continues to work on many relevant policies, this discourse of female empowerment is believed to have prompted several initiatives by both prefectural administrations and businesses. For instance, the governors of Yamaguchi, Miyazaki, and Saga prefectures publicized an online video wherein they engaged in household chores while wearing pregnancy bellies. Alongside these developments, corporations from across the country have been joining an unfolding campaign to promote a corporate culture with childcare-sensitive managers ( $i k u b o s u$ ) at its center (Fathering Japan, 2017). In these examples, the distant goal of a society where women "shine" is perceived as something that can be achieved through men's firsthand understanding of traditional women's domains, such as bearing and rearing children. These initiatives simultaneously promote a gentler image of men, distinct from the long-standing picture of hardworking males who are physically absent from their familial homes (Street, 2013), and as such, these campaigns critically highlight that WLB is an issue for both genders.

These initiatives are undoubtedly a step towards reconstructing gender roles; however, many earlier (Roberts, 1994) and more recent (Aronsson, 2015) works have demonstrated that when it comes to real life, household chores and childcare continue to fall largely to women in Japan, even when they hold outside jobs. Nakatani has argued that while policies "to encourage men's sharing of domestic responsibilities" have begun to appear, the general economic climate "is far from favorable for such governmental initiatives" (2006: 104-105). The following section contextualizes this situation by providing an overview of women's employment in postwar Japan.

\section{Overview: Women and Employment in Japan}

Since the end of World War II, the female labor participation rate has risen, growing by $22 \%$ between 1953 and 1972, and by a further $32 \%$ between 1972 and 2000 (Statistics Bureau, 2017). A steady decline in family-run businesses took place both within and beyond the agricultural sector, a domain in which women had previously worked to generate income for their families. This shift pushed women to seek outside employment (Rebick, 2006). Other trends have included an increase in part-time work and the diversification of the female labor force (Macnaughtan, 2006). The employment situation for women with full-time jobs in Japan has improved in regard to sexual harassment, hiring practices, the number of women in management, and the gender pay gap, thanks to Equal Employment Opportunity Laws of 1986 and 1999 (Rebick, 2006). Other regulations related 
to family policies, such as 1994 and 1999 Angel Plans, were adopted to improve childcare provisions (Varlamova, 2014).

Today, the OECD reports that young women in Japan are better educated than young men, yet they are less likely to be employed (in 2017, 28.9 million women were in labor force, as opposed to 36.8 million men). If women do have jobs, they are more likely to be irregular employees, a reality that contributes to the persistent male-female wage gap: at the median, women earn $73 \%$ of men's salary (OECD, 2015). Female employment in Japan is characterized by an M-shaped graph: Women often quit their jobs upon marriage or the birth of children (Inoue et al., 2016). There are multiple factors responsible for this situation: intrafamilial pressures, a lack of child care, and unsupportive workplaces (Aronsson, 2015: 6). In other industrialized countries, this M-shaped pattern reportedly disappeared in the 1980s (Saeki, 2008: 190). For women in Japan who resume working upon their children reaching a certain age, irregular employment is often the only option. Japan's policies regarding tax exemptions for dependents discourage women from applying for jobs exceeding a certain income level (Roberts, 2016: 5). While one argument holds that women attain WLB-related flexibility through irregular work patterns, this flexibility is often illusionary: part-time working hours are not necessarily shorter than full-time ones, while a lack of training and promotion opportunities for part-time workers prevents career advancement (Broadbent, 2002). As such, these individuals do not have an opportunity to escape the "imposed" flexibility as they move through life. Further, the reality that the majority of part-timers in Japan are married women highlights how "employers are preempting women's choices" in terms of these women's perceived preference for flexibility (Broadbent, 2002: 16). In fact, females working part-time have been reported as having "difficulties in achieving a work-life balance" (Inoue et al., 2016). Married women, and especially mothers, who choose to pursue a career in Japan despite all the structural factors present at every level of societal and familial life must face what Varlamova (2014: 14) has summarized as "exceedingly high alternative expenses in terms of improving the quality of individual human capital." For women who decide to work full-time, long hours are an inescapable reality: Aronsson has reported that in the absence of female role models, career women in Japan design their professional paths in accordance with the male career model (2015). As such, compared to women in other countries, women in Japan are often made to choose "between their career and raising children" (OECD, 2015) if they want to succeed in either domain. The following statistics provide context: according to a 2016 survey, in households with children in which both parents work, women perform $89 \%$ more household-related work (including childcare) than men on a weekly basis (Ministry of Internal Affairs and Communications [MIC], 2016).

Brinton, in her detailed account of female employment in Japan since the post-war period, described the role of women in Japan as "indirect participants: they have nurtured higher-priced male labor" as both unpaid domestic workers and "inexpensive labor to employers" (Brinton, 1994: 12). Nearly 10 years later, Broadbent made a similar observation, noting that Japanese women's "involvement in public life including full-time paid 
work is perceived as conflicting with the appropriate and effective conduct" of a woman's domestic role (2002: 7). Rebick is more optimistic, noting that contemporary women are "less likely to be barred outright from developing careers in firms" (2006: 87). At present, academics rightfully fear that Japan's prime minister Shinzō Abe’s seemingly proactive stance on women's economic integration (the so-called "womenomics") would only benefit a small number of female elites. In contrast, the majority of women would continue to play a crucial yet peripheral role in Japan's economy, while also being the first to bear all the negative effects of neoliberal deregulation (Schieder, 2014).

The situation of women in Japan is of interest, as the "women's question" is unresolved in that industrialized country. "A statistically egalitarian arrangement" has not yet been achieved (Ogasawara, 1998: 6). Unlike the majority of industrialized countries, where the sex-role revolution has been considered central to the industrialization processes, Japan has maintained a "sharply delineated sexual division of labor" (Briton, 1994: 11). With Japan's plans to revive its economy-which has been stagnating post-bubble but is reportedly on the mend today-it is of interest to investigate how the gender contract will play out at the advent of the second quarter of the twenty-first century and whether the public preoccupation with the concept of WLB will generate the momentum necessary to reconstruct gender roles.

\section{Methodology}

This study, which is methodologically rooted in multimodal critical discourse analysis (MCDA) and narrative inquiry, explores online commercials, both product-oriented and non-product-oriented, to address representations of men's and women's gendered identities where these representations serve to produce or reproduce WLB discourses. The videos were identified via a YouTube search using preset keywords, such as working fathers/ mothers, men/women at work, and WLB (in Japanese). For the purposes of this paper, three recent videos were selected, although over a six-month period, I viewed dozens of online videos on the subject. Major tropes ${ }^{1}$ appearing in these videos were identified; the three videos were chosen for illustrating the most frequently encountered tropes from various angles. The three videos that are discussed in this paper are "I-am-sorry lunchbox," "Mommying Drive," and "It's okay." The spoken text in the videos was transcribed to facilitate the analysis. The selected videos portray women in slightly different situations, and hence, in multiple gender and WLB arrangements: a housewife, a part-time worker, and a full-time worker. The first video (a non-product one) belongs to the social advertising domain, while the second is a product-oriented commercial. The third video grew out of the correspondent company's branding strategy; while it does not promote specific products, the video serves to emphasize the company's social consciousness.

Further contributing to the multidimensional approach of this study, the results draw on discussion threads and inquiries that the author developed in 2017 to target working

\footnotetext{
1. See Negra (2009) for an example of an analysis of gendered tropes in the media.
} 
mothers in Japan. These discussions focused on the very same videos. All participants were asked to watch the three videos and answer the following two questions: "What is WLB for you?" and "What were your thoughts and feelings after watching the videos?" The call for research participants was sent to a Line group of mamatomo (i.e., women who have befriended each other through childrearing activities; 3 women, all Japanese) and individually transmitted through both Facebook and Line to 6 more women (5 Japanese women and 1 Russian woman). Further, a request for participation was posted in the "Working mothers in Japan" Facebook group for Russian women (49 people), one of the platforms on which my cyber-ethnographic investigation centered. For this group, participation was incentivized, as the participants were offered gift cards.

In total, 12 women responded to the survey, either in the discussion thread or through private Facebook and Line messages: To ensure consistency, I utilized responses from 5 Japanese women and 5 Russian women, as 2 women did not fully match the established demographic criteria. The author engaged solely in digital communication with the participants, both to achieve coherency with the digital materials on which the participants were asked to comment and to extract the maximum amount of data while minimizing the burden on the already-busy participants-working mothers. At this stage of the research, I recruited participants from my private networks and from groups on social networking websites that I employ for larger ethnographic inquiries. While this approach presented certain limitations ${ }^{2}$, it made it possible to incorporate into the analysis the larger contexts pertaining to these women's individual circumstances.

Working mothers are not the only ones who experience difficulties in achieving balance in their lives. Nevertheless, their stories are perhaps the most straightforward example of the WLB's preoccupation with balancing work and family, and it is for that reason that this project targeted that population. There are also factors explaining why not only Japanese women, but also Russian women (who migrated to Japan post-199os and are predominantly married to Japanese men) were selected as participants. Firstly, my research in Japan since 2008 has primarily focused on Russian migrants (Golovina, 2017), and recent findings from a joint project have revealed that these women also face many constraints when trying to balance their professional and familial lives in Japan (Mukhina, Golovina, 2018). In that joint project, an important result surfaced: Russian women in Japan primarily experience difficulties in that country in relation to work and family not because they are foreigners, but because they are women (Mukhina, Golovina, 2018). This finding is of interest; in terms of the gender gap, Russia ranks 75 (a smaller gender gap) while Japan ranks 111 (out of 144 countries). Moreover, female enrolment in tertiary education is particularly high in Russia, as is the share of professional and technical workers who are women. In regard to economic participation and opportunity, the female-to-male ratio is 0.72 for Russia and 0.57 for Japan (World Economic Forum [WEF], 2016). Once relocated to Japan, however, Russian women's ability to serve as adepts of egalitarian values is severely constrained. Finally, the current project focused on Japan

2. See Khosravinik and Unger (2016: 217-223) for an example of focus group-based research conducted via Facebook and a discussion of the potential limitations. 
as a locality, with the goal of identifying the structural factors which determine how the WLB-related realities of that country's inhabitants, regardless of their ethnicity, play out.

\section{Theoretical Framework}

Van Dijk, one of the founders of critical discourse analysis (CDA), stated in his lecture that those who hold positions of power must be careful about the messages they send (2013). Otherwise, they risk inadvertently constructing, or re-constructing, a discourse that could be damaging to certain populations. While all the videos selected for this project seem to be both entertaining and optimistic, what are the discourses they transmit? Are any latent and potentially harmful messages embedded in them? If so, who do they empower, and who do they marginalize? These questions are tackled in the analysis section.

Traditionally, CDA aims at "deconstructing ideologies and power through a systematic and retroductable investigation of semiotic data" (Wodak, Meyer, 2016: 4), and it is effective at "giving voices to the voiceless" and "exposing power abuse" (Blommaert, Bulcaen, 2000: 449). As such, critique, as a constituent element of CDA, "regularly aims at revealing structures of power and unmasking ideologies" (Wodak, Meyer, 2016: 6). Wodak and Meyer argue that "in modern societies, power and domination are embedded in and conveyed by discourses" (2016: 6). Janscary et al. (2016: 183) state that discourse "is performative and constitutive, rather than representative. This means that social reality is a human achievement and could be-at least in theory-constructed differently."

Drawing on Van Dijk's rhetoric, Wodak and Meyer (2016: 3) emphasize that CDA per se is not a method of analysis, but an approach to critically investigating discourse in a certain social context through a broad array of methodologies. They opted to employ a more neutral term-critical discourse studies (CDS) — and specified that it "has never attempted to be or provide one single or specific theory" (Wodak, Meyer, 2016: 5). Scholars of CDS are required "to translate their theoretical claims into instruments and methods of analysis" (Wodak, Meyer, 2016: 14).

To extract the discourses pertaining to WLB from the selected videos and then critically examine them, I drew on MCDA, which is a form of CDA used to investigate texts consisting of multiple modes-such as written and spoken words, images, and musical accompaniment. According to Janscary et al. (2016: 185), the mutual relationships among modes are not unilineal; various combinations suggest "particular versions of social reality that are not neutral with regard to power: they serve some interests while marginalizing others." Janscary et al. (2016: 184) wrote that "visualization, due to its fact-like character, is particularly suited to supporting the truth-claims of its authors." It is thus highly pervasive, making the discourses transmitted through visuals easy to internalize. The genre of the text often contributes to this pervasiveness; for instance, the persuasive techniques adopted in advertising generate the power behind product-oriented videos, thus multiplying the effects of the discourses they convey. 
In MCDA, there are a number of approaches to critically investigating text. The two strategies referenced in this paper are an archeological approach ("that looks for traces of meaning in existing visual discourse") and a dialogical approach ("that uses visuals to initiate communication with actors in the field" [Janscary et al., 2016: 186]). Methodologically, Janscary et al. (2016: 190-191) describe a multilayered technique that first looks at the individual modes contained in the multimodal text. The next phase is an integrated analysis of those modes, followed by a critical evaluation of the broader discourse, and this method can be applied through a series of steps. In this paper, I analyze the three videos according to Janscary et al's five-step methodology, which I adapted slightly to better suit this study. The initial steps in their methodology are: (1) characterization of the genre, (2) capture of the manifest content, (3) reconstruction of latent elements, (4) composition, (5) conclusions and critical evaluation. The steps I use in the analysis below are: (1) short description, (2) context of the video, (3) characteristics of the genre, (4) manifest content, (5) latent elements and the interrelationships among the modes, (6) critical evaluation. This process consists of peeling off layers of meanings until the underlying discourses were exposed.

\section{Results: Online Videos}

\section{Japanese Commercials}

The genre of the commercial is highly developed in Japan, dating back to a 1953 Seiko commercial (Akiyama, 1993). Currently, many commercials are produced exclusively for internet viewers and are known as onrain dogga, an approach that allows producers to incorporate a wider range of techniques and to reach more diverse audiences without time limits. Akiyama has stated that one of the distinguishing features of Japanese commercials is that the concept of "family" is a central theme (1993: 91). He further emphasized that many commercials are akin to mini-dramas or stories. This feature is also characteristic of onrain dogga; they often employ heartwarming narratives focusing on family life. Although Akiyama mentioned that the producers of Japanese commercials do not particularly emphasize social issues and that public service advertising is rare in Japan, the situation has changed, and many commercials now concentrate on social issues. In response to the array of societal problems currently facing Japan, WLB is a trending topic, and many companies have developed their commercial agendas by utilizing WLBrelated discourses, riding on the popularity of WLB as a progressive vision of a conscious individual.

Online video-sharing platforms enable viewers to openly discuss and interpret videos. This situation has led to a series of heated discussions (known as enjō, literally "flaming") surrounding a few commercials for which the producing companies became the target of heavy criticism for various reasons (including sexism) and were called upon to stop streaming those items. While the videos in this study have been actively discussed online on multiple websites, no demand to ban them followed, and they continue to be available online. 


\section{Analysis of the Selected Videos}

\section{Video 1: I-am-sorry lunchbox}

\section{SHORT DESCRIPTION}

This video depicts a father who prepares o-bentō (a boxed lunch) for his daughter and wife. When they get home, he hands them their lunchboxes as a gesture of gratitude for their support throughout the years.

\section{CONTEXT OF THE VIDEO}

This social advertising piece was created in 2016 as part of the "Kyushu-Yamaguchi WorkLife Balance Promotion Campaign." The more popular video mentioned in the Introduction-in which the prefectural governors completed household chores while wearing pregnancy bellies - was also a product of this campaign, initiated by the Kyushu Region Strategy Council; it consists of nine governors and heads of regional business organizations (Asahi Shimbun, 2016). The council's website states that in Japan, women perform seven times more household chores than men do. The project suggests that understanding the importance of balancing both work and family life, along with creating a work environment amenable to childrearing, could help alleviate this situation. Implementing a WLB vision would, in turn, promote men's participation in household chores and childrearing. The governors and leading board members who led the project positioned themselves as "dandies"; in this context, the word is meant to suggest that these men are capable of understanding the hardships that women undergo, engaging in housework, and caring for children.

\section{CHARACTERISTICS OF THE GENRE}

"I-am-sorry lunchbox" is a 2:05-minute non-product commercial with 7,149 views on YouTube as of May 2017. As a multimodal text, "I-am-sorry lunchbox" brings together visual depictions of people and objects, and these are accompanied by music, spoken words, written text, photographs, designs, and colors. Moreover, emotional actions, such as laughing and crying, are articulated both orally and visually. The designs and colors of the clothing and interiors - and more importantly, the food-depicted in the video bring forward the underlying contexts and appeal to viewers' senses. Towards the end of the video, statistics appear on-screen in the form of graphs and numbers, in line with this piece's mission as a social advertisement.

\section{MANIFEST CONTENT}

The visual element, which is dominant in this video, consists of a succession of mise-enscenes and written text. This text appears in white and introduces the title of the video

3. The number of views should not be considered as absolute. While I utilized a particular link (https://m. youtube.com/watch?v=I_zd6wBJUtg) for the analysis, this video has also been shared online in other places (as well as via the official website of the organization that originally posted them). As such, the total number of internet views is impossible to determine. The same consideration applies to all three videos in this paper. 
and a description of the characters. In contrast, the spoken language is kept to a minimum in the video. The scene opens with natural light and the sound of birdsong, reinforcing the relaxed atmosphere. The song playing in the background is in English, and the lyrics state, "When you are not here, a picture in my life, I love you still, when you are not at my side..." Next, a man appears in the scene, and he is cooking. Annotative text tells the viewers that he is a "father, 44 years old" and an "office worker." He wears an apron and is experiencing difficulties with cooking, underscoring his lack of regular participation in this activity. Rice sticks to his fingers, and he proceeds to lick it off, further intensifying the intimate atmosphere of the video. The father is heard talking to himself; "Please, wait!" he intones, as he struggles to keep an eye on every piece of the meal simultaneously. Viewers can hear his onomatopoeic exclamations, and the father's clumsiness suggests that the kitchen is not his regular domain. From that point onwards, mise-enscenes of him cooking alternate with shots of family photographs, creating a kaleidoscope of his memories. All three family members appear in photographs depicting various moments of their family life. The photographs are accompanied by written messages, which represent the father's inner thoughts. In the first photo, the family is captured swimming in a pool. The father looks younger in this image, and this is also the first time that we see the mother and the daughter. The on-screen message reads, "Sorry that I always come home late." The second photo depicts a family outing, perhaps an aquarium. The father is striking a humorous pose, and the text states, "Sorry that I don't do much around the house." By this point, the lunch is almost ready. The father sits at the table surrounded by plates of delicious-looking food. He then begins to arrange the dishes inside the lunchboxes. He uses scissors to cut seaweed into small shapes, and he uses ketchup to decorate the meal. This process seems time-consuming, and it appears to require a significant amount of effort on the part of the father. At the end, however, he seems content with the results. A final photo then appears: In it, the two parents are wearing suits, while their daughter is in a school uniform. The photo appears to have been taken in a residential area after some sort of official event, most likely related to the daughter's school life. This photo also appears to be more recent; the father looks like his present self. The on-screen text reads, "Sorry for always having to say sorry." The lunchboxes are finally ready, and the father is satisfied. In fact, he is giggling. Against a white screen, the text announces: "From the father. A lunchbox with love." This is his message to his family. At this point, the daughter appears, followed by her mother. They both look surprised when they see that the father seems to be plotting something. It is at this point that the majority of the video's verbal language is spoken. The accompanying music disappears. The father hands the pink lunchbox to his daughter and says, "I usually can't give presents, but I would like to give you this present from the bottom of my heart." He then proceeds to apologize to his daughter that he has not had enough time for her in the past. He attempts to tell her that this lunchbox is his way of apologizing, but he does not complete the utterance. This is the only time in the video that he verbally produces the word "sorry." The father then hands the next lunchbox, which is yellow, to his wife. Among other dishes, it contains an omelet with the word "love" written in ketchup on top of it. The father goes on to tell her 
that he made the food with love. He sounds more confident than when he had spoken to his daughter. The family exchanges a few jokes and laughs. The mother praises the father, and then both mother and daughter proceed to thank him. The father is then seen shedding a tear, to which the daughter responds that if he starts crying, she will as well. The mother does not cry, however. The music, which had paused during the interaction, resumes. Two lunchboxes are shown as narrative-style text in the upper left-hand corner of the screen appears. It states, "When one engages in household chores and childrearing, one becomes more effective at work. There is data supporting this." Three graphs appear on-screen with supporting statistics. In the concluding mise-en-scene, the mother and the daughter eat from their lunchboxes; the mother feeds the father a piece of what appears to be fried chicken. The initiative's title ("Kyushu-Yamaguchi Work-Life Balance Promotion Campaign") then appears at the bottom of the screen.

\section{LATENT ELEMENTS AND THE INTERRELATIONSHIPS AMONG THE MODES}

The previous section described the manifest content of the video. Here, I focus on the hidden elements communicated through the modes employed in the video and on the interrelationships among them. The father makes o-bentō for his family to apologize for causing them difficulties through being constantly busy with work, and hence, his habitual absence. However, the video does not tell us anything about the specifics of these difficulties. Instead, it creates the impression that the father has, in fact, been present in the lives of his wife and daughter. He is not only the central figure in the majority of mise-enscenes but also a part of each photograph that appears on the screen. Therefore, although he apologizes to his family for having been too busy with work to spend time with them, the viewers are told that he was able to attend family outings and important events. The photographs also suggest that he has been able to provide for his family members to the extent that they could afford to participate in recreational activities together. The modern design of their spacious home also supports this claim, and these elements serve to rehabilitate the father.

Viewers are offered a considerable amount of information about the father, thanks to the annotative text. The third photograph shows him wearing a lapel pin. Although we know from the earlier annotative description that he is an office worker, this photo suggests that he may have a prestigious title. Thus, his age and occupation and status are revealed to viewers. In contrast, little information is provided about the women in the video. The daughter's status is introduced when she is depicted wearing a school uniform. We also learn her name when the father speaks to her upon handing over the lunchbox. There is no annotative text to further describe her, however. The identity of the mother remains completely concealed. She is not named in the video, and no annotative text introduces any of her demographic characteristics. In the third photograph, she is wearing a white suit, which is a common outfit for women in Japan on the occasion of their children beginning a new grade in school. As such, the video positions her as conforming to societal conventions. Interestingly, the video's written text represents the "voice" of the 
narrator and of the father. The video's female characters are not given this kind of "voice" but instead express themselves through spoken words.

When the father hands the lunchboxes to his daughter and his wife, the family shares a moment of what can be interpreted as catharsis; this emotional occasion is reinforced by the strong sunlight entering the room through the window. Both the father and the daughter shed tears, and there is thus a touch of pathos to the moment. As if to diffuse the atmosphere, the mother comments kindly on her husband's ability to prepare o-bentō. Although undoubtedly touched, she does not emerge as an active participant in the emotional exchange. The question remains as to whether she has accepted the apology. Although it is her who has experienced the most difficulties due to her husband's absence, it is the father and daughter who are crying, but viewers do not receive clarification as to why this is the case. When the family gathers around the table at the end of the video, there is another detail to consider: The father has cooked lunch as a gift for his daughter and his wife but has not prepared any food for himself. As the mother feeds chicken to her husband from her lunchbox, we are reminded of her role as a caregiver in the family.

\section{CRITICAL EVALUATION}

The previous steps made it possible to address the various "languages" embedded in the text and to extract the discursive elements transmitted through the video's different modes. What is the message that this video conveys? What kind of WLB discourse does it communicate? The male figure is central to this video's message. He is seen as an active creator of his life and as a provider, while his family-and particularly his wife, about whom the viewers are told nothing-are constructed as the recipients of his time, wealth, and gifts. The concluding message, supported by the statistics presented in graphic form, suggests that when people participate in household chores and childrearing, they become more productive at work. Since the person in the video who participates in household chores-albeit on a one-time basis - is a man, the video's concluding message appears to be addressed to men. This explains why depictions of women engaged in household chores and childcare are absent from the video; the WLB discourse transmitted through the video sends the message that men can maximize their productivity at work by taking a more active role in the familial domain. As such, one's mode of being outside work is construed as supporting one's status as a worker, where "performance at work is understood as being influenced by all aspects of a worker's life" (Kelly, 2013: 176).

While commercials naturally only illustrate a fragment of someone's life, the video contains ample evidence suggesting that this initiative may indeed remain a one-time undertaking. The father does not proclaim that he will continue to make lunch for his family. Rather, he himself does not have any lunch at the end of the video and thus needs to be fed. He also positions the lunch as a "gift," and presents are given on special occasions. He reinforces this interpretation by stating that he is "usually" unable to give any presents. The choice of a "present" is also of interest: In Japanese culture, o-bentō is a powerful symbol that functions to both please the receiver and affirm the virtue of the maker (Allison, 1991). The father verbally says "sorry" only once; in other instances, his 
"sorry" appears as written text accompanying the photographs. However, viewers are introduced to the time and effort he put into making the lunch, and that care illustrates the depth of his apology. Clearly, if he were to engage in such an activity on a daily basis, his actions would no longer be infused with the sense of "festivity" that accompanies them in the video. The message that this video communicates is that in reality, the situation cannot be changed and the father will continue to be absent. He has performed a "heroic deed" resulting in catharsis; he has demonstrated his understanding of his family's hardships and his desire to offer a genuine apology. Perhaps it is for this reason that we do not see the mother crying. She has accepted the apology but realizes that her husband will continue to devote himself to his work. Thus, she will continue caring for the household, just as she has done for over a decade, either in addition to, or, as is most likely, instead of pursuing her own interests outside of the family.

\section{Video 2: If dad became mom for one day: Mommying drive}

\section{SHORT DESCRIPTION}

Three fathers take part in an experiment. They have their hair and make-up done and change into their wives' clothes. They then go about the day as if they were their wives; as if they were the mothers of their children. They take their children to daycare and other activities, cook for them, and play with them. In the end, they are exhausted.

\section{CONTEXT OF THE VIDEO}

"Mommying drive" is a commercial that Nissan, a Japanese automobile manufacturer, released in January 2017. The video features one of the company's automobiles-the Serena, a family-style minivan for which the firm released a new model last year. Nissan's promotional webpage for the Serena states that the company decided to conduct an experiment on January 31 in which fathers spent the day like mothers; their activities were then filmed. January 31 is known as Beloved Wives' Day in Japan, although this occasion is not widely celebrated. In the video, the Serena is branded as a product with the potential to ease the lives of mothers. Although the video is a commercial, its content suggests that it contains the results of a filmed social experiment.

\section{CHARACTERISTICS OF THE GENRE}

The full-length version of this commercial, available on YouTube, is a 5:45-minute-long video with 5,095 views as of May 2017 ${ }^{4}$. On Nissan's webpage for the Serena, the video is introduced as a "movie," and a "behind the scenes" page provides supplementary material, further underscoring the video's supposed status as a real film. The video has both a Japanese title and an English one. Neither is in translation; rather, the two titles complement each other. The Japanese title reads "If dad became mom for one day," while the English title is "Mommying drive." Here, "mommying" is an improvised verbal adjective, 
rooted in the improvised verb, "to mommy." If "to mommy" means to engage in activities associated with motherhood, then a "mommying drive" represents a car trip characterized by such activities. In terms of multimodality, the video combines written text, spoken text, the sounds of drums, musical accompaniment, typing noises, and children's wailing and crying.

\section{MANIFEST CONTENT}

The video is characterized by an abundance of visuals that rapidly shift back and forth, contributing to the hurried atmosphere. Three families appear, one after another. They are questioned by an invisible interviewer-narrator. The interviewer-narrator asks the fathers a question ("Do you participate in household chores and childrearing?"), which appears as written text against a black background. The fathers reply in spoken words that are simultaneously subtitled in white on the bottom of the screen. As the fathers reply (with their answers supplemented or edited by their wives), the interviewer-narrator proceeds to comment on the situation ("The men do not know." "How hard it is for mothers." "Let us make them experience it." "Being a mom."). These comments also appear as white text against a black background. The statements are segmented into shorter phrases, with the last comment appearing in larger font for dramatic effect. Each question and comment on the part of the interviewer-narrator is accompanied by the sound of fast typing. A pulsing drumbeat is present throughout this section of the video, and an intense atmosphere is maintained throughout.

The first family consists of four people: a middle-aged father and mother and two children, approximately five years old and two years old. The father says, about his participation in household chores, that he makes breakfast. The second family also consists of four people. This middle-aged couple have two boys, who are approximately five years old and three years old. Without confidence in his voice, this father replies that he is responsible for the task of bathing the children. There are six children in the third family, ranging in age from a few months old to approximately six years old. The father sits with two of these children on his lap. There are two women present, one of whom is the mother and the other is perhaps a relative or baby-sitter. The father seems confident. He says that since he had lived alone for a long time, cooking is not a problem for him. The interview is complete; at this point, the interviewer-narrator announces to the fathers that they will now be asked to become mothers. The interviewer-narrator speaks aloud here for the first time. The title of the video appears on the screen in both Japanese and English. The makeover session resumes as the fathers have their hair and make-up done and change into clothes similar to those their wives are wearing. The video then fastforwards to the fathers' re-appearance, which is accompanied by brass instruments. The couples pose for photos, and the men now resemble their wives. The women give their husbands small notebooks with the schedule for the day. Each of the fathers-turnedmothers' detailed schedules for the day appear on-screen under the title "Mission" (such as: "10:30 Drop off son at daycare"). The accompanying sounds resemble computer-game sound effects that might play at the beginning of a new round. 
From that time onwards, written descriptions of the father's respective errands appear on-screen as the fathers-turned-mothers go about their days. The video first follows the experiences of father-turned-mother № 2. "She" encounters multiple obstacles, such as dropping fruit and having a stroller fall over backwards from the weight of the groceries in it. As the father-turned-mother runs with the stroller, a stopwatch appears in the center of the screen with a reminder: "She" only has 1 hour, 1 minute, 31 seconds, and 8 milliseconds left until "she" must pick up "her" son from baseball practice. The need to hurry is thus reinforced. Father-turned-mother № 1 appears next. We see "her" fixing makeup and struggling getting out of the car in high heels. As we see "her" running to the office, the stopwatch appears.

Viewers are given a short glimpse of father-turned-mother № 3. "She" is in the car and surrounded by children, one of whom is crying. From that moment, shots of each of the fathers-turned-mothers' activities are interspersed with each other. This mixture creates a dizzying sensation of chaos, hurriedness, and unpredictability. We learn that a mother's day does not contain even a second to rest. Father-turned-mother № 3 looks exhausted. We see "her" leaning on a shopping cart in an absent-minded fashion while grocery shopping with "her" children. The day concludes; father-turned-mother № 1 is driving home on a highway at night. "Her" infant, in a car seat behind "her," will not stop crying. Although the viewers hear this sound for only a few seconds, it is overwhelming, as all other sounds have been silenced at that point. The mission is over. The families reunite at Nissan's showroom where the men, who have changed back into their usual clothes, reflect on their day. They make comments such as: "Mom is doing an amazing job" and "There was not a single second to rest." One of the wives says, "It feels good to be understood." The narrator's text appears across the screen against a black background: "The men have noticed." This message from the narrator is no longer accompanied by a typing sound. The sense of tension dissolves, and the music becomes more relaxed. The remaining segment of the video, which this paper does not analyze in detail, combines the families' consultations at Nissan showroom and the "behind the scenes" section.

\section{LATENT ELEMENTS AND THE INTERRELATIONSHIPS AMONG THE MODES}

In this video, the role of the interviewer-narrator is of particular interest. In the majority of cases, his utterances take the form of written text accompanied by the sound of typing. Employing such a mode of representation serves to depersonalize him, while at the same time placing him in a position from which he can oversee the entire situation, in terms of both its immediate details and its connection to larger societal structures. Hence, he is seen as possessing the ability to comment on the fathers' words and actions. We hear him speaking only once; in the voice of a male, the narrator invites the fathers to take part in a social experiment in which they will become mothers. He is thus seen as possessing masculinized powers that allowed him to modify reality. Thanks to this experiment, the fathers realize the hardships their wives experience. Metaphorically, the interviewernarrator is a type of a "deus ex machina," due both to his ability to alter how events unfold 
and to the literal presence of a "machina": the Serena. This automobile is presented as capable of alleviating the difficulties these mothers face.

The gendered nature of male and female roles emerges as the central theme of the video, and various visual modes, such as the styles and colors of the clothing depicted, serve to intensify the message. The fathers are not simply asked to experience the busyness of their wives' agendas by following their schedules. Rather, they must do so in settings in which they are compelled to go beyond their gender through extensive cross-dressing. The fathers use different voices when they wear women's clothes, although it is not clear whether they do so on purpose. The embeddedness of household chores and childcare as women's tasks is depicted as so deep-rooted that a man requires a full bodily transformation to perform them. To engage in "mommying," they have to look like women. Paradoxically, by being feminized when they perform these chores, the men in the video avoid being demasculinized, as a man who looks like a man cannot do what a woman does.

Other men and women in the video are also seen engaging in gendered work. The daycare staff, department store retail assistant, and nail technician are all female. The only shop assistant who is a male is the one selling coffee beans, a luxury good. Technically, once outside the door of the Nissan showroom, the fathers-turned-mothers find themselves in a women's world. In contrast, the Nissan sales clerks are all males.

A few occurrences during the office scene (which takes place in a one-room space) require further mention. Here, women's work is represented as document-related deskwork. The father-turned-mother № 1, who is now a female worker, is asked to make a spreadsheet but is not given clear instructions. A superior explains the content counting on her fingers, as if she is explaining something to a child. The over-simplified explanation appears to be puzzling for the father-turned-mother, however. "She" - who is, in fact, a "he"-seems to need a more sophisticated explanation to comprehend the task. The other people in the video and the fathers' interactions with them thus function as another "language," or mode, of power and serve to construct certain types of female realities. There is another exchange that takes place in the same office. A female coworker touches the father-turned-mother's false breasts through "her" pullover, asking, "What is this?" While this scene can be interpreted as a brief unmasking, with the man's true identity revealed in a humorous manner, it nevertheless implies women's lack of autonomy in the workplace.

\section{CRITICAL EVALUATION}

In the previous sections, I analyzed both the manifest and latent elements articulated through the various modes incorporated in video. In this section, I examine the discourses constructed through the enactment of these elements. I explore this video's vision of WLB and the solution it offers. Similar to "I-am-sorry lunchbox", Video 2 acknowledges the lack of balance in women's lives. The female characters are pictured as speeding through their days with no time for professional growth or rest. Only one of the three women is depicted as having a daytime job, which she must attend from noon until four 
in the afternoon. The manner in which this job is illustrated, detailed above, suggests that this is not a career-track occupation. To balance work and family, this woman has chosen to be an irregular employee. Although a redistribution of household chores and childcare duties could lead to her being more active in her work life, feeling less overwhelmed with childcare, and having time for leisure, the video does not challenge these circumstances but instead presents them as given. The situation is further mystified by this woman's increased engagement with beautifying, including her visit to a nail salon. As such, the video indicates that she has achieved a certain degree of freedom relative to the two other women, but this independence is exemplified in a highly feminized way.

While the video does much to convey the difficulties that women experience on a daily basis, the solution that it offers in fact intensifies the traditional division of roles. A woman's identity is set in stone: She is a "mommy," and what she does is "mommying." Men are provided with an opportunity to understand the intensity of these mothers' labor and to mitigate it by purchasing a suitable car for them. To afford the vehicle- and hence, to keep their wives content-the men need to work more. As such, consumer culture emerges as opposed to balanced WLB strategies for both genders. The one-time nature of what has occurred is reinforced not only by the cross-dressing but also by the fact that the social experiment takes place on Beloved Wives' Day. Thus, similar to Video 1, the men's actions essentially represent a gift to their wives. However, in this video, catharsis is achieved not through an apology but through the men's realization of their wives' ongoing efforts, an awareness that they gain after engaging in "mommying."

\section{Video 3: It's okay}

\section{SHORT DESCRIPTION}

This video displays a working mother conversing with her male coworker about the hardships of childrearing. She suggests that mothers do not feel sufficiently appreciated. We then see her picking up her sick child from daycare. As she walks back home, she contemplates her life as a mother and worker.

\section{CONTEXT OF THE VIDEO}

This video is a commercial by Cybozu, a Japanese software company. Unlike the previous video by Nissan, this commercial does not advertise any product. Rather, it focuses on a concrete social issue (i.e., the daily struggles of working mothers). On its website, the company calls this production, originally released in 2014 as an animated piece, a "workstyle drama." As such, the company's branding strategy is to position itself as socially conscious. The slogan ("Cybozu stands with working mothers") appears twice during the video. 


\section{CHARACTERISTICS OF THE GENRE}

"It's okay" is a 5:20-minute two-part commercial with 60,212 YouTube views as of May $2017^{5}$. In terms of multimodality, the video combines visual depictions of people and objects; non-captioned words spoken by various characters; on-screen descriptions in the form of written text; a smartphone video that one character shares with another; musical accompaniment; the sound of a child crying; instant messages exchanged by the characters; urban landscapes; varying weather conditions; and the advertising company's slogan, which appears after the first and second portions of the video.

\section{MANIFEST CONTENT}

In general terms, the first part of the video focuses on the heroine at her workplace, while the second part captures her life after she leaves the office. The first part opens with a conversation between the heroine, Ôsawa (who is approximately in her mid-thirties), and her male coworker. He shows her a video of his young child, complaining that despite the fact that he "helps" his wife (who presumably also works, as they have started sending the infant to daycare) with childrearing, she is always angry with him. Their conversation is not captioned. Ōsawa notices that her male coworker uses the verb "to help" and replies that his wife must be genuinely thankful, but that childrearing is very hard on mothers and that what mothers ultimately need is to be taken care of themselves. From that moment onwards, the camera focuses on Ōsawa's face. Flashbacks appear of moments that she has found challenging as a mother. A chanson accompanies these flashbacks, and the music emphasizes the emotional dimension. Ōsawa's facial expressions and unarranged hair present a stark contrast to her appearance at work. Each of the visual episodes of childrearing is supplemented by a short description that appears on-screen as written text: "Cries unless held" (on putting her baby to sleep), "The next time will be in three hours" (on bottle-feeding at night), "Run to be on time for the daycare pickup" (on combining work and mothering), "One hundred roundtrips in the hallway" (on soothing the infant), "Make it tastier" (on the infant refusing to eat bland baby food), "Encounter with a virus" (on receiving a phone call from daycare at work when the child is sick), "Why stop now?" (on the child refusing to walk), and "Weighs 15 kilograms in no time" (on walking while holding the toddler). These visual episodes progress in time with the child's growth; the viewer is invited to note that while the content of the difficulties changes, their intensity does not. The majority of these written descriptions, which are short although rich in content, represent the narrator's voice. They are interspersed with Ösawa's inner voice, and this narrative is thus not voiced to her male coworker. The pitch of her voice is different when she is talking to her male coworker versus when she is engaging in these internal conversations. We do not see her verbally uttering these inner thoughts. Rather, they accompany the flashbacks. There are elements of dramatization due to the persistent use of the ni kagitte grammatical form in Ōsawa's internal narratives

5. https://m.youtube.com/watch?v=HJ7QhL9oeKA. This video, due to its realistic nature, remains highly popular, as the Discussion section makes clear. The number of views at this particular online location continues to grow, with a nearly $80 \%$ increase between May 2017 and September 2017. 
("The child just has to throw a fit and refuse to walk when I am busy," "The child just wants to be held when I am tired.").

While the viewer has an opportunity to see into Osawa's inner world and to understand why she told her coworker that childrearing is hard on mothers, her coworker does not have the same chance. He is thus left sitting and looking at her as she is lost in her thoughts. He ultimately asks if she is okay in a concerned manner. His voice brings Ōsawa to her senses. She replies, "Exactly. Such kind and concerned words are what make a mother persevere." The coworker seems puzzled by the simplicity of her suggestion when Ōsawa adds that he should hug his wife from time to time. She then goes about her day in the office.

The second part of the video shows Ōsawa outside of work, although here there are a few flashbacks to her office life. This interrelationship between the themes, demonstrated by their interspersed depiction, highlights the mutual dependence of one's public and private life and of the distribution of one's time and efforts. The second part of the video is titled "It's okay", and these words appear in large-sized font across the screen. The segment follows Ōsawa as she picks up her child, who has developed a fever, from daycare. It is early evening, and the pair walks home together. The verbal exchange between the child and the mother is limited. At first, the boy only asks the mother to pick him up, which she does. The mother does not seem to be emotionally present in the unfolding situation. Similarly to when she was talking to her coworker, she dives into her own thoughts. This time, she is considering the issue of balancing her responsibilities as a mother and as a worker on that particular day. Her internal dialogue is highly nuanced. As she cannot take the next day off work, she contemplates childcare options in case her son's fever persists. The pitch of her internal voice varies. She sounds hopeful when she thinks that she may manage to book byōji hoiku (i.e., a childcare option for kids who are sick and cannot attend their regular daycare facility) for her sick child. However, her optimism fades quickly. If she does manage to book a spot there, she will need to cook a boxed lunch for her child, which will mean another night of missed sleep. She walks slowly, displaying evident fatigue, up a bridge lit by the sunset. This motion, along with her uphill steps, suggest connotations of hard work and endurance. As she continues thinking, the boy asks her, "Mommy, are you okay?" Once again, this is what brings her to her senses. Her presence is short-lived, however, as she then dives back into her inner world, asking herself if she is indeed okay. Her inner world seems to be full of intense self-doubt. She asks herself, "Am I a good worker? Do I love my son enough? Do I love myself at all?" These questions are again interspersed with visuals of her difficulties: She receives a critical comment when making a presentation at work, her child refuses to walk despite heavy rain, she stands in the rain doubting herself. In this final image of her in the rain, her face appears in slow motion. This is the most dramatic part of the video. The overwhelming effort that she makes to balance work and family has led her to resent herself. The flashbacks disappear, and Ōsawa and her child are again on the bridge. They have, however, already completed the climb, having overcome the steepest part of the journey home. From now on, their journey is on a flat surface. Ôsawa is now emotionally 
present with her child, and she repeats the words "It's okay, it's okay" to him. The tension disappears, as the boy agrees to keep walking, and the mother and her son continue on hand-in-hand.

\section{LATENT ELEMENTS AND THE INTERRELATIONSHIP AMONG THE MODES}

In this video, the two coworkers-Ōsawa and a male colleague-are both wearing white shirts with a company card hanging around the neck. They both have black hair and are presumably in their thirties. When the man addresses the woman, he only uses her family name without an honorific suffix. They must have entered the company at the same time or have similar responsibilities. As such, they are visually portrayed as in possession of a similar working identity. However, we soon learn that for the woman, although she is naturally held to the same standards at the workplace, her identity as a worker is just one of her many identities. Being an involved mother is another one, and it requires ongoing effort. The male coworker shows Ōsawa a smartphone video of his child, but we do not see Ōsawa doing the same. She is more careful when it comes to revealing her identity as a mother in the workplace setting. Although she thinks about her child, she does not speak about him, not even to her male co-worker in a conversation about childrearing. Her lack of comment suggests that motherhood may not be an identity that is praised in corporate settings.

The video portrays Ōsawa in a variety of situations, in various weather conditions, at different times of the day, and in clothes ranging from work attire to pajamas. What is remarkable, however, is that she is almost always shown alone. In the video, she mainly interacts with her male coworker, her child's daycare provider, and her child. Her husband, the boy's father, is absent, regardless of the time of the day and the setting. We are made to notice his presence only once, when a human body moves under the bedcovers while Ōsawa is bottle-feeding in the middle of the night. When Ōsawa works from home in dim light after her child has fallen asleep, she is again alone. We thus know that the father returns home very late at night. A brief text message exchange between Ōsawa and her husband takes place when she is on the bus on the way to pick up her sick child. He replies to her inquiry as to whether he can pick up the child with the message: "I'm sorry, I just saw your message. The meeting wouldn't finish..." The time on the smartphone is 16:48; we are told that it was the mother who made the sacrifice of leaving the office early despite having an important meeting. The father was not able to see her message until she had already boarded the bus. He is depicted as a typical salary man working around the clock, and WLB is a notion with which he seems to be entirely unfamiliar. The mother's WLB seems to be the result of forces beyond her control, and her situation does not seem to be what she desires. She manages to both work and parent at the cost of always being in a hurry and of being unable to achieve satisfaction from either.

This video offers a multitude of voices. The mother's internal dialogues represent an important mode in this multimodal production, and they voice underlying meanings. She is depicted as constantly trying to convince herself that her situation is not as hopeless as it looks; there are things that only women can do, and so trying to involve her 
husband is not necessary. Although she is frustrated with the fact that she is the only parent who picks up and drops off the child at daycare, she does not seem to be angry at her husband, and she accepts his lack of participation as a given. After a series of flashbacks illustrating her in difficult and energy-consuming childrearing situations, she nevertheless says, right before advising her male coworker to hug his wife more often, "It is not that all these [experiences] are painful, but make sure to be kind to moms." This presents a sharp contrast with the visual narrative: When the video shows Ōsawa as engaged in childrearing, she never smiles, and she is often irritated and exhausted. Moreover, she walks slowly, as if purposeless or as if she is simply going through the motions. In short, she is unable to focus on the present moment. What she is experiencing is beyond painful. While Ōsawa is perhaps undergoing a stress-induced burnout, she is depicted as accepting her fate. She knows that all she can aspire to is some kindness, a gentle question inquiring if she is okay and a hug from her partner.

\section{CRITICAL EVALUATION}

The underlying discourse of this video is that of acceptance of one's fate and gender role, corroborated by the deep embeddedness of male and female work and parenting patterns in Japanese societal structures. These structures are illustrated as unchangeable, precluding a reconstitution of gender roles that could potentially lead to a better WLB for both men and women. The heroine's husband is so immersed in his work life that his communication with Ôsawa is almost fully digitalized. His only "movement" outside of work is restless sleep in a dark room. It is as if he is not alive when not at work. He is thus unable to participate in childrearing. The more proactive generation of men who do participate in child-reading do so to "help" their wives; they are called ikumen, and Ōsawa uses this same word. Roughly translated as a "childrearing father," this compound word is similar to a "working mother" in that at first glance, each adjective seems to be uncharacteristic of the respective gender. With no support from her own husband-he never asks her, "Are you okay?"- Ōsawa is aware of the increased burden that she faces in trying to juggle multiple identities. For her, as it is for many working wives and mothers, home is no less of a labor site than is the workplace (Hochschild, Machung, 1989). However, she neither challenges her own situation nor the larger social structure. Thus, the discourse that permeates this video is that both genders remain unable to achieve a WLB strategy that is satisfying for them. In the case of the husband, his identity as a worker is solid. As he devotes all his time to work, it is there that his identity-related ambitions lie. The mother is unable to be content with either of her roles and thus spends her days doubting herself. As such, the video is in line with the larger "work-family narrative" where working mothers are expected to be "bad managers, bad mothers, or both" (Padavic et al., 2015: 8). In the absence of proposing a solution, this video sends the message that being aware of a mother's sacrifices, occasionally asking her if she is okay, and giving her a hug will encourage her to persevere. Similar to the first two commercials analyzed in this paper, the men are encouraged to express empathy. 


\section{Results: Real Voices of Working Mothers in Japan}

In this section, I present and analyze the narratives of Japanese and Russian working mothers in Japan that were gathered as part of this project. The original narratives were in Japanese and Russian but were translated into English for the purposes of this paper. This section employs a dialogical approach to MCDA, as the visual materials were used to trigger conversations with the research participants. The participants were working mothers with young children. All of the 10 women were in their early 30 s to early $40 \mathrm{~s}$ and held different jobs with various time demands (e.g., full-time/part-time/freelance/ maternity leave) and resultant incomes. The participating women were asked to watch the videos and to answer the questions: "What is WLB for you?" and "What were your thoughts and feelings after watching the videos?" Some participants commented on only one or two videos, and others left a single comment about all three pieces. The narratives are grouped according to the key codes within them; the key codes are thematically summarized before each of the narrative groups. A few central codes are supplemented by the original Japanese words that the participants used. In each narrative, the larger set of codes utilized for the analysis is underlined. A handful of narratives that voiced themes unrelated to this study were excluded. Finally, while there were some curious differences in how the Japanese and Russian women perceived the videos (e.g., their understanding of the function of food as an element of the videos), this paper does not discuss those factors, as doing so is beyond the scope of this study.

\section{Question 1: What is WLB for you?}

Enjoyment; satisfaction (nattoku):

(1) It means living my life with enjoyment. It is living in accordance with one's personal ideal balance: It should be acceptable to either fully devote oneself to work or care only about one's private life. Currently, I find work more important, but because I spend a lot of time doing chores and taking care of my children, I wish I could reduce [the time I spend on] these.

FO, late 3os, mother of 3, Japanese, freelance relationship counselor

(2) Work-life balance is doing work that I want to do and caring for my kids to the extent that makes me satisfied.

CY, mid-3os, mother of 2, Japanese, adjunct lecturer and researcher

Appreciation; emotional leeway (yoyzu); a revolution in mindset (ishiki kakumei):

(3) The kind of life where I work, but also appreciate the time with my kids on a daily basis. I live my life thinking how nice it would be to have the emotional leeway to read a book to my kids before they fall asleep. On the other hand, I feel unsatisfied with how I work, and so I wish my husband participated more in household chores and childrearing. (However, it's difficult to have a revolution of mindset, so progress is slow.)

HF, late 3os, mother of 2, Japanese, office worker 
Fine-tuning (totonoeru); satisfaction:

(4) To fine-tune relationships with other people and the content of my work in a way that leaves both myself and the people around me satisfied.

AI, late 30s, mother of 1, Japanese, full-time lecturer

The sense that childrearing is suffocating; work as motivation and emotional support:

(5) For me, work-life balance is the last but absolutely necessary piece to make me feel positively about childrearing. I often feel suffocated if all I do is care for my kids, so if there is an environment where I can work the way I like, this would be motivation that would provide emotional support in dealing with the difficulties of childrearing.

YA, late 30s, mother of 2, Japanese, freelance writer

Family as a priority; work as emotional support:

(6) For me, most likely, work is second, and my family and child are first. I work, because I love my work, and I like it that my brain is working. I also make my own schedule. So, if my child is sick, I will always move my work to stay with my child or invite a babysitter my child likes. For me, considering whether to put my child into daycare for sick kids is completely unacceptable. What kind of work is this where everything will burn down without her [the heroine from Video 3]? I would only do that kind of work for a tremendous amount of money, but I would find a fulltime nanny. Our dad [EZ's husband] takes an active part in childrearing, so I do not feel that everything is on me.

EZ, late 3os, mother of 1, Russian, part-time tutor and entrepreneur

Family as a priority; work as a financial means:

(7) As for work-home balance, for me my family is the priority. I only work in order to support my family financially. I am not developing a career, since I realized I did not need one.

KP, mid-3os, mother of 1, Russian, office worker

Doubts; compromise; balancing:

(8) For me, work-family balance is what Video 3 shows. It is constant doubts: "Am I a good mother? Am I a good worker?" It is a constant state of having to make a compromise somewhere, of [knowing that] balance, normal balance, is impossible, that there is no support, that I do everything on my own. Although in my case, if my child is sick, it is my husband who will take a day off. His company provides better conditions for this. Nevertheless, when balancing work and family, you always think about others, about family or work. Is there time to think about oneself? And, are you even allowed to?

$\mathrm{OB}$, mid-3os, mother of 3 , Russian, adjunct lecturer 
(9) For me, it's not just work-life balance, but work-myself-family balance, to be precise. For me, balance is precisely akin to a pendulum swinging to one side and then the other. If my inclination to work is only stressing me out, I decrease my workload, and vice versa.

AS, mid-3os, mother of 2, Russian, adjunct lecturer

Living in the moment; problems with balancing:

(10) Work-life balance [is what works for me] for the moment. I will still have lots of jobs in my life, but my kids are growing fast. With the eldest child, it was approximately what Video 3 shows. Everything was on me. So, for the last six years, I have been a homemaker on a prolonged maternity leave. I am thinking of going back to work, but everything is going to be like in Video 3, only twice as hard.

NK, late 30 , mother of 2, Russian, homemaker

\section{Question 2: What were your thoughts and feelings after watching the videos?}

\section{Video 1: I-am-sorry lunchbox}

Unrealistic; men's hardships at work; lack of emotional leeway:

(1) FO: Firstly, I felt that it was unrealistic. It would be nice to have a husband like that, but they do not exist. There are a lot of men who are extremely tired from their work. They experience a lot of stress, and so they do not have the emotional leeway to even contemplate the idea of preparing a lunchbox. I felt that it was a fairytale. It would be more realistic to show how men get tired, how tough the work is on them. I wish they focused on how many men work too much and that they are confined to their companies for long hours. If they show that the company has changed, and that the man's vision has thus transformed as well, and then that was followed by him making a lunchbox for his daughter and wife, I would then be convinced.

Unrealistic; saccharine:

(2) OB: Video 1 is like a tall tale. I do not believe it is possible-although it looks nice. It leaves you with the feeling that this is a one-time occasion. So, he cooked dinner, everyone cried. What's next?

(3) AS: $\underline{\text { Saccharine }}[\ldots]$.

Women's burden:

(4) NK: Mom is somewhat "tormented" and looks at her husband as if he were her second child. What I felt after watching it is that if the husband knows how to cook, what is so special about this lunchbox? If it is his first lunchbox, [I imagine] what a mess he then left behind him in the kitchen, judging from the variety of dishes. 


\section{Video 2: Mommying Drive}

Desire to be understood:

(1) HF: I would like to have this experiment carried out in my home! It would be nice if my husband understood firsthand that chores do not simply mean cleaningcooking-laundry.

Desire to be understood; lack of emotional leeway:

(2) CY: I liked the second video the most. In my heart, I wish to be understoodthe hardships mothers undergo, the difficulties of multitasking, and the burden when everything is half-finished, because there is no time and emotional leeway. All dads should undergo this experiment!

Unrealistic; desire to be understood:

(3) FO: I wish there were a real experiment like this! It would be nice if this kind of project became a TV show. I cannot help but feel that this video is fiction. Unless they show in more realistic terms how a dad snaps and yells at his kid, or how the room is completely trashed while the father is cooking dinner and how the father gets upset because of that, it won't appeal to the viewers. A mother's day is not as simple as it is shown. However, it's nice that dads can experience how hard it is for moms with some humor and laughter.

Informative; potential for social impact:

(4) YA: I thought that unlike commercials that talk about ideas and ideals [...], [Video 2] provides details (how they incorporated moms' ideas into their products, how male customers from three couples took part in a staged experiment [...]) and would thus have more social impact and value.

Commercialized; unrealistic; unsophisticated:

(5) KP: It is too commercialized, so I wasn't touched. Everything is mixed together and unclear; there is no straightforward message (except for "buy this car," of course!)

(6) OB: It felt like it is more of a car commercial. [...] Funny, of course, crossdressing men. But, where would a working mom find time for getting her nails done? What kind of work is she doing? For half a day? So, it didn't touch me [as it was not realistic].

(7) AS: Too unsophisticated. 
Commercialized; feminized depiction of women:

(8) NK: It's a great idea to leave kids with daddy for a day, but why torturing them? Wigs, makeup, shoes? If they wanted to torture [men], cross-dressing would have been enough, while to experience a mom's day, [asking them to watch the] kids would have been enough. And, of course, it is a blunt commercial for a car and its manufacturer. [...] If I were a man, my conclusion after this experiment would have been that all the problems and "lack of time" are due to all of these meaningless women's things, so I would have given my wife a pair of sneakers and sportswear.

\section{Video 3: It's okay}

Realistic; women's burden; change of mindset; fine-tuning:

(1) FO: I felt that this video was the most real, and it made me feel emotional. The environment of working mothers is often unfriendly, and in reality, a mom's burden is extremely heavy. However, it also made me feel that it is important for moms, for women, to change their mindset, too. There are too many mothers who think that they have to do everything on their own. I think that the working environment would change a lot if mothers themselves understood that it is okay for someone other than them to raise their children and do household chores, and that there is nothing wrong with that. It would be nice if it were easier to ask someone around to help. As just asking for help becomes a reason for emotional distress, it is important for society as a whole to change its mindset. In this video, we hear the mom's inner voice. This is what everyone feels but is afraid to show, even to their own husband. Mothers have to be braver to share these feelings with their husbands, and husbands have to make it easier for their wives to share. When a couple's communication improves, a good relationship is born, which will lead to the fine-tuning of one's work-life balance.

Appalling; women's burden:

(2) OB: I have watched this video before and even posted it on Facebook, and my friends who do not speak Japanese were asking me what this video was about. They also were appalled, even without [understanding] the language. Every single moment is precisely what it is, even how men expect to be praised for what they do at home. He took his child to daycare-it's a reason to boast-while women do 10 times more, and every day. And, all this is taken for granted.

Realistic; chilling; sad:

(3) NK: Video 3 is the reality of life in Japan. The mother's main work is the child and home, and she is allowed to do some work to satisfy her ambitions when the child is in daycare. At the same time, the father happily displays photos and videos [of his child] and excitedly tells everyone what a good job he is doing. Most of my acquaintances here live according to this order. 
(4) KP: The second part of this video chilled me to the bone, but I was confused as to why the person from whom one is expecting the most support was never shown. It is pessimistic, in the end, that her colleague asked her how she was, and that her kid did the same, but that the father is apparently on a trip to outer space.

(5) AS: Too sad.

\section{Discussion}

The women's narratives revealed multiple themes related to WLB (Question 1). Firstly, only some of the participants employed the term "work-life balance" using those exact words. Many of them instead modified this term when answering the question. The variants that they used included "life-work balance," "work-home balance," "work-family balance," and "work-myself-family balance," and each of these reflected the participant's particular situation and priorities. For many women, WLB had to do with "satisfaction," "enjoyment," "appreciation," or "loving one's work." This finding suggests that the WLB to which the women aspired did not concern allocating the proper amount of time to certain activities. Rather, in the participants' eyes, WLB was more a question of being satisfied with what one does both at work and at home. In the case of work, being content seemed especially important for many respondents; when a passion for one's work was present, it functioned as a type of "emotional support" that helped the women feel positively about themselves (EZ's "I like it that my brain is working") and about their role as a mother, otherwise "suffocating" (YA) and thus oppressive. On the other hand, in terms of factors inhibiting their ability to feel content, the women cited a lack of "emotional leeway" or a reduced psychophysiological capacity to engage in certain activities beyond a set of daily actions.

Some women emphasized the role of "fine-tuning one's relationships with other people" in achieving the desired WLB. This suggests that WLB is experienced not as an individualistic issue, but as a shared value in the context of one's ongoing relations with family, friends, and society as a whole. As AI mentioned, WLB must be organized in a way that leaves others feeling "satisfied" as well. As such, a woman's desired WLB cannot be achieved in isolation and must involve a degree of reciprocation; however, the women's narratives suggest that they were the primary mediators in this process of mutual adjustment.

Some women underlined "doubts" that caused them to question their identities as workers and mothers. This uncertainty emerged, because one always has to "make a compromise somewhere," be it work or home. As such, OB described a "normal balance" as impossible to realize. According to $\mathrm{OB}$, balancing efforts can turn into a selfless enterprise if all that one does is "think about others." Those who attempt to manage and balance everything to attend to everyone's needs, will find themselves only managing to meet the basic essentials of life. The situation of these coping women, as pointed out by the participants in this study, would then resemble that of the heroine in Video 3, only "twice as hard" (NK). 
Cases arise in which other people do not understand a woman's struggles to combine work and household chores. In connection with this, HF mentioned the importance of adjusting one's "mindset" so that a mutually satisfactory WLB can be achieved: She hoped that her husband would become more proactive in doing housework and caring for children. In addition, EZ, who seemed to have found her balance through viewing her work as secondary to her role as a wife and mother, cited her husband's active involvement in childrearing as an important factor for achieving that balance.

In their responses to Question 2, some of the women provided their general impressions of the videos, while others addressed the material more critically. Their responses contained themes similar to those that arose in the above discussion on defining the concept of WLB. Interestingly, the women judged the videos in terms of how life-like they found them, and the participants reported feeling untouched by those that did not feel sufficiently realistic or that were too "saccharine." Many of the participants described Video 3 as the most realistic; the women reported feeling emotional and "chilled to the bone" after watching it. It was also described as "pessimistic" and "sad." Many of the women said that they identified with it. This suggests that the reality of these women's attempts to balance work and family life in Japan is not joyful. That said, FO stated that the situation could change for women in Japan were they to alter their "mindsets" and stop thinking of themselves as the only ones responsible for household chores and childcare. She also stated that women should be "braver" in articulating their needs. Finally, she stressed that this "transformation of mindsets" must be a collective effort on the part of the country as a whole. Many women said that they wished that their spouses "understood" them, and they particularly voiced this desire in response to Video 2, which enacted this sentiment in a strong way. This lack of understanding was corroborated by the perception that women's unpaid labor is "taken for granted" (OB). KP reported experiencing strong disappointment when she realized that in Video 3, Ösawa was not going to receive any emotional support from her husband, the person from whom she most needed that sense of caring. This finding demonstrates that the women in the study internalized the transmitted discourse; they did not believe that a true reconstitution of gender roles-and hence, of WLB - was possible. They were thus content with being understood.

Women referred to housework and childcare in a number of ways. These ranged from describing themselves as "suffocated" by "hardships" to more concrete depictions (e.g., "difficulties of multitasking," "chores do not simply mean cleaning-cooking-laundry," "everything was on me," "working mothers' environment is often unfriendly," "a mom's burden is extremely heavy," and "women do 10 times more, and every day"). However, personal hardships were not the only problem that the participants voiced. The long working hours and stress experienced by men-both those depicted in the videos and these women's husbands and friends-were named as a structural factor in need of attention. 


\section{Concluding Remarks}

This multidimensional study investigated contemporary WLB discourses communicated through Japanese digital media in recent years. It also examined how these discourses are perceived by a specific viewing population - working mothers in Japan-and provided members of this group with the opportunity to articulate their WLB experiences and visions. The analysis revealed that the dominant WLB discourse embodied in the studied videos is one that presents harmony as something to be achieved not through men's equal participation in the family domain and greater balance for women, but through a series of often-unexpected "heroic deeds" by men. In the videos, these deeds led to much-needed moments of catharsis but failed to instigate the reconstitution of gender roles that could ultimately make possible a better WLB for both genders. In concrete terms, each video contains a trope in the form of men's apologies to, and understanding of and empathy for, women. These actions are positioned as a promise of the women's continued perseverance to carry the domestic burden. While the women in the study did voice their desire to be understood by their partners, I argue that this wish originates from the embeddedness of gender roles and work-related identities in Japanese society, as well as from the women's internalization of the dominant discourse, which offers a compromise but not a solution. Men went as far as cross-dressing to demonstrate their understanding of women. This action, however, did not empower the women in a way that permitted them to choose more personalized modes of being as regards the content of work, patterns of work, childcare options (e.g., intrafamilial versus outsourced childcare), and leisure activities beyond beautification (which NK referred to as "meaningless women's things").

The study participants described their experiences with WLB and their visions of this concept, highlighting the importance of communality, proactive communication, and nuanced adjustment. They likewise cited satisfaction and emotional leeway as elements missing from modern-day lifestyles. Within relationships, one person's success at achieving a desirable WLB usually depends on the other person's WLB, which, in turn, depends on the structural forces at play. People may not always be willing to negotiate these structural forces, as doing so means letting go of their hard-earned identities (Williams et al., 2015). For instance, many men in Japan do not welcome regulations aimed at discouraging people from working too much, as such policies would threaten their corporate male identity (Nemoto, 2016). The collected narratives underscored that at the moment, it is mostly women who are receptive to the WLB discourse, to the extent that they not only seek to manage their own work and home, but also unconsciously strive to leave their partners undisturbed. These women fine-tune their own routines in a manner that ensures that their male partners are satisfied. With respect to their efforts, the emerging keyword is "coping," rather than "shining" envisioned by politicians. Without the reconstruction of gender roles, the WLB discourse may do more harm than good for the female population. I argue that the discursive postulation of new and diverse forms of identities could encourage people to redefine their aspirations, reassess their identi- 
ties, listen to their partners, and devise mutually enriching WLB strategies. Perhaps, it is when those goals have been achieved that both women and men will "shine" in Japan.

\section{Acknowledgments}

An earlier draft of this paper was presented as part of the panel "Towards Further Discussion on the Work-Life Balance Concept in Anthropology: An Exploratory Review to Lay the Groundwork for Research on Japan" held at the $51^{\text {st }}$ Annual Meeting of the Japanese Society of Cultural Anthropology in Kobe, Japan, May 2017. I thank the panel's discussant Ayami Nakatani and my co-panelists Kiyomi Doi, Kaoru Kuwajima, and Gaku Moriguchi for their insightful comments and suggestions. I also thank the anonymous reviewers of this paper for their constructive feedback.

\section{References}

Akiyama K. (1993) A Study of Japanese TV Commercials from Socio-Cultural Perspective: Special Attributes of Nonverbal Features and Their Effects. Intercultural Communication Studies, vol. 3, no 2, pp. 87-114.

Allison A. (1991) Japanese Mothers and Obentōs: The Lunch-Box as Ideological State Apparatus. Anthropological Quarterly, vol. 64, no 4, pp. 195-208.

Aronsson A. S. (2015) Career Women in Contemporary Japan: Pursuing Identities, Fashioning Lives, London: Routledge.

Asahi Shimbun (2016) "Pregnant" Men Find How Tough Housework is for Their Wives (by K. Narisawa). Available at: http://www.asahi.com/ajw/articles/AJ201611060012. html (accessed 5 May 2017).

Blommaert J., Bulcaen C. (200o) Critical Discourse Analysis. Annual Review of Anthropology, vol. 29, pp. 447-466.

Brinton M. (1994) Women and the Economic Miracle: Gender and Work in Postwar Japan, Berkeley: University of California Press.

Broadbent K. (2002) Flexibility at Work? The Feminisation of Part-Time Work in Japan. Journal of Industrial Relations, vol. 44, no 1, pp. 3-18.

Fathering Japan (2017) IkuBoss Project. Available at: http://fathering.jp/ikuboss/ (accessed 5 May 2017).

Golovina K. (2017) Nihon ni kurasu roshiajin josei no bunkajinruigaku: Ijū, kokusai kekkon, jinseizukuri [Russian Women in Japan: Migration, Marriage, and Life Crafting], Tokyo: Akashi Shoten.

Hochschild A. R., Machung A. (1989) The Second Shift, New York: Avon Books.

Ikezoe H. (2014) Work-Life Balance in Japan: Outline of Policies, Legal Systems and Actual Situations. Japan Labor Review, vol. 11, no 1, pp. 108-124.

Inoue M., Nishikitani M., Tsurugano S. (2016) Female Non-Regular Workers in Japan: Their Current Status and Health. Industrial Health, vol. 54, pp. 521-527. 
Jancsary D., Höllerer M. A., Meyer, R. E. (2016) Critical Analysis of Visual and Multimodal Texts. Methods of Critical Discourse Studies (eds. R. Wodak, M. Meyer), Los Angeles: SAGE, pp. 180-204.

Khosravinik M., Unger. J. W. (2016) Critical Discourse Studies and Social Media: Power, Resistance and Critique in Changing Media Ecologies. Methods of Critical Discourse Studies (eds. R. Wodak, M. Meyer), Los Angeles: SAGE, pp. 205-233.

Kelly P. (2013) The Self as Enterprise: Foucault and the Spirit of 21st Century Capitalism, Farnham: Gower.

LDP. (2014) Liberal Democratic Party Political Promises. Available at: http://jimin.ncss. nifty.com/2014/political_promise/sen_shu47_promise.pdf (accessed 5 May 2017).

Macnaughtan H. (2006) From "Post-war" to "Post-bubble": Contemporary Issues for Japanese Working Women. Perspectives on Work, Employment and Society in Japan (eds. P. Matanle, W. Lunsing), Basingstoke: Palgrave Macmillan, pp. 31-57.

MIC. (2016). 2016 Survey of Social Life. Available at: http://www.stat.go.jp/data/ shakai/2016/pdf/youyaku2.pdf (accessed 9 September 2017).

Mukhina V., Golovina K. (2018, forthcoming) Zainichi roshiajin josei ijūsha kara mita gaikokujin josei no rōdōshijō he no tōgō: jendā shiten kara no kōsatsu [Labour Market Integration of Russian Women in Japan: A Gender Perspective]. Tabunka kyōsei kenkyū nenpō (Annual Review of Multicultural Studies), vol. 15.

Nakatani A. (2006) The Emergence of "Nurturing Fathers": Discourses and Practices of Fatherhood in Contemporary Japan. The Changing Japanese Family (eds. A. Takenaka, M. Rebick), London: Routledge, pp. 94-108.

Negra D. (2009) What a Girl Wants? Fantasizing the Reclamation of Self in Postfeminism, London: Routledge.

Nemoto K. (2016) Too Few Women at the Top: The Persistence of Inequality in Japan, Ithaca: ILR Press.

OECD. (2015) Japan Policy Brief. Available at: https://www.oecd.org/policy-briefs/japan-greater-gender-equality-for-more-inclusive-growth.pdf (accessed 8 August 2017).

Ogasawara Y. (1998) Office Ladies and Salaried Men: Power, Gender, and Work in Japanese Companies, Berkeley: University of California Press.

Padavic I., Robin J. E., Reid E. (2015) The Work-Family Narrative as a Social Defense. Available at: http://www.hbs.edu/faculty/conferences/2013-w50-research-symposium/Documents/Gender_and_work_web_update2015.pdf (accessed 5 May 2017).

Rebick M. (2006) Changes in the Workplace and Their Impact on the Family. The Changing Japanese Family (eds. A. Takenaka, M. Rebick), London: Routledge, pp. 75-93.

Roberts G. S. (1994) Staying on the Line: Blue-Collar Women in Contemporary Japan, Honolulu: University of Hawaii.

Roberts G. S. (2016) Japan's Evolving Family: Voices from Young Urban Adults Navigating Change, Honolulu: East-West Center.

Saeki J. (2008) Beyond the Geisha Stereotype: Changing Images of "New Women" in Japanese Popular Culture. A New Japan for the Twenty-First Century: An Inside Overview 
of Current Fundamental Changes and Problems (ed. R. T. Segers), London: Routledge, pp. $187-197$.

Schieder C. S. (2014) Womenomics vs. Women: Neoliberal Cooptation of Feminism in Japan. Meiji Journal of Political Science and Economics, vol. 3, pp. 53-60.

Statistics Bureau (2017) Labor Force Survey: Historical Data. Available at: http://www. stat.go.jp/english/data/roudou/lngindex.htm (accessed 8 August 2017).

Street Z. (2013) Absent Fathers: Fatherhood in Moral Education Textbooks in Postwar Japan. Manga Girl Seeks Herbivore Boy: Studying Japanese Gender at Cambridge (eds. B. Steger, A. Koch), Wien: LIT, pp. 83-128.

van Dijk T. (2013) Discourse and Knowledge. Available at: https://www.youtube.com/ watch?v=sxfc-WJRKEM (accessed 11 November 2016).

Varlamova M. (2014) Semeinaya politika v Yaponii [Family Policies in Japan]. Demoskop Weekly, no. 589-560, March 10-23, 2014. Available at: http://www.demoscope.ru/ weekly/2014/0589/demoscope589.pdf (accessed 8 August 2017).

WEF. (2016). Global Gender Gap Index 2016. Available at: http://reports.weforum.org/ global-gender-gap-report-2016/rankings/ (accessed 10 October 2017).

Williams J. C., Berdahl J. L., Vandello J. A. (2015) Beyond Work-Life "Integration". Annual Review of Psychology, vol. 67, pp. 515-539.

Wodak R., Meyer M. (2016) Critical Discourse Studies: History, Agenda, Theory, and Methodology. Methods of Critical Discourse Studies (eds. R. Wodak, M. Meyer), Los Angeles: SAGE, pp. 2-22.

\section{Гендерный контракт в онлайн-рекламе в Японии: критический анализ современного дискурса «баланса работы-жизни»}

\section{Ксения Головина}

$\mathrm{PhD}$, ассистент-профессор, Центр стратегий глобальных коммуникаций, Токийский университет Адрес: Komaba 3-8-1, Meguro Ward, Tokyo, Japan 153-8902

E-mail: kgolovina@cgcs.c.u-tokyo.ac.jp

Данная статья, в которой применен подход, основанный на мультимодальном критическом дискурс-анализе, рассматривает, как дискурсы, относящиеся к популярной концепции «баланса работы-жизни», выражаются в доступных в Интернете японских рекламных роликах. Далее, в исследовании анализируются нарративы проживающих в Японии работающих матерей, в которых последние делятся своими впечатлениями от просмотренных видео, а также идеями о «балансе работы-жизни». Таким образом, в статье предпринята попытка изучить влияние дискурсов, передаваемых через рекламу, на восприятие женщинами своих идентичностей как работников, партнёров и матерей. Детальный анализ мультимодальных данных позволил определить скрытые дискурсы «баланса работы-жизни», а также гендерных ролей, воспроизводимых в видео. Эти неявные дискурсы многолинейны и в большинстве случаев состоят в отношениях противоречия 
с ключевым сообщением анализируемых рекламных роликов. Один из центральных посылов в извлеченных дискурсах - стимулирование однократных «героических поступков» японских мужчин по отношению к женам, выражающих мужские виноватую позицию и понимание ситуации женщин. В то же время, нарративы участниц исследования обнаружили их личное видение желаемого «баланса работы-жизни», одновременно выявив процесс бессознательного усвоения ими дискурсивных установок, передаваемых через рекламные видео. Цель исследования связана как с расширением области применения методов критического дискурс-анализа, так и с обогащением дискуссии, касающейся переформирования гендерных ролей, необходимого для внедрения в Японии как публичных, так и частных стратегий «баланса работы-жизни».

Ключевые слова: «баланс работы-жизни», мультимодальный критический дискурс-анализ, онлайн-реклама, гендерные роли, работающие матери 